mathematics and, concurrently, that more universities should develop major research schools in at least one specialized branch of applied mathematics.

The committee, which appears to have reached its conclusions independently of any outside opinions or surveys of students or researchers in the field, felt that far too many students and staff remained divorced from practical work in their fields. While undergraduates should spend at least two years studying a mixed course in pure and applied mathematics, both to give them a firm grounding in mathematical reasoning and to give them time to decide in what area they wish to concentrate, the committee emphasized that those students interested in applied mathematics should be aware of the practical aspects of at least one special field of application. To this end, there should be closer cooperation between the mathematics department and science, engineering and other departments at the university. Students should be encouraged to work on problems outside their own department, possibly in government or industrial laboratories, during the vacations.

Two members of the council of the Royal Society, Professor D. G. Kendall of Churchill College, Cambridge, and Professor C. A. Rogers of University College, London, dissented from the committee's strong emphasis on practical work and put forward a more modest view in an appendix to the report. They point out that it is often not practical to draw a line between "pure" and "applied" mathematics and that repeated interchanges between the two should be encouraged. With this in mind they stress that a general education in "pure" mathematics, even for those students who are primarily interested in mathematical applications, should continue beyond the first two undergraduate years. They also believe that technical proficiency is not a necessary criterion and that many students are so incompetent at technical work they would be deterred from studying for a postgraduate degree if practical work was required. While they agreed that in many instances practical research was useful, they concluded that experimental work for postgraduate applied mathematicians should never be compulsory.

Parallel to its study of graduate training, the committee looked at the research schools in applied mathematics at British universities and colleges. A survey of fifty-one institutions indicated that only nineteen had adequate "major" research schools in at least one branch of applied mathematics. The report concluded that every university should turn at least one minor school into a major one by concentrating resources in that one field and strengthening links with research in other university departments. But the committee was happy to find that topics covered were not unduly unbalanced and there were only two fields at present where the lack of a major research school was deemed harmful-control theory and general statistical mechanics and physics. Both of these fields were covered by minor research schools at six institutions, but none were sufficiently developed, according to the standards of the report.

This report is the fourth in a Royal Society series covering postgraduate training in the United Kingdom. Reports of the committees on chemistry, physies and biology have been published within the past year and engineering and earth sciences are still to come. Interesting and informative though this present report is, it is far too limited in its scope; it is unfortunate that the committee neglected to seek the opinions of people in the field and failed to coordinate its work with that of the other committees. A comprehensive study of postgraduate scientific training in Britain would have been more welcome; let us hope that the two remaining reports go some way to answering this need.

\section{Drug's Loss, Health's Gain}

THE new Secretary of Health, Education and Welfare in Washington has President Johnson's blessing for dramatic changes in the organization of his sprawling department. Not that HEW is to be split into three parts, which might be the best idea. (The US Govern. mental Manual of government organization needs four pages to list, in fine print, the names of the senior officials with responsibility for the federal government's programmes in the widely scattered and barely related fields of education, medical research and social benefits.) The department's responsibilities will remain enormously, almost derisorily wide. But the two biggest changes to be noticed immediately are the demotion of that excellent agency, the Food and Drug Administration, and the realization that policy-making, on a national level, is what American health and welfare needs most.

The man at the top, Mr Wilbur Cohen, has already been named by President Johnson as his leading adviser on health and welfare problems. That may sound like labelling the obvious but-assuming that the President listens to the advice-it means that America's domestic social problems are now being weighed at the White House with something like the gravity of defence or science. Perhaps there is more to rejoice at in the news that $\mathrm{Mr}$ Cohen will lead a new Interdepartmental Health Policy Council. It is intended to have the status of the President's Council of Economic Advisers (which has just succeeded in persuading a most unwilling Congress to vote for a rise in taxes in an election year). The kind of issue which the council will take up is the maldistribution of doctors and hospitals among the American population, the Negro and the rural getting far less than a fair share.

Whether the shake-up will be good for the crusading Food and Drug Administration remains to be seen. The FDA, from which the director, Dr James Goddard, resigned a few weeks ago, gets transferred to a new service which is to be created within the Public Health Service (which, led by the Surgeon General, is under the HEW department's jurisdiction). The new entity is to have the clumsy title of Service for Consumer Protection and Environmental Health. As well as food and drug regulation, it will supervise various national centres for radiological health, control of pollution in the air, urban and industrial health, and communicable diseases. In the bureaucratic jungle of HEW, therefore, the Consumer Protection Service will be on a par with the National Institutes of Health: both are subordinate to the Public Health Service. Until now, the FDA, which kept thalidomide from being approved for sale in the United States and which now is on a most relentless drive to force harmful or useless medicines off American shelves, had operated more or less independently. There is even talk that, for efficiency's sake, FDA might someday be killed off 
entirely, its consumer protection role being taken over by the new service and its research into the efficacy of medicines to be handed over to branches of NIH.

The past year has not been a happy one for either HEW or the FDA. Both heads have resigned, Mr John Gardner having left the secretaryship when the department was not given increased funds in the face of the most crying social needs. (It is rumoured that he has been offered Robert Kennedy's Senate seat, which is still unfilled.) Yet $\mathrm{Mr}$ Cohen, the new secretary, like Dr Herbert Iey, jun., who succecds Dr Goddard at the FDA, is expected to continue the crusading work of his predecessor, with perhaps more attention to tact. Yet those who expected Mr Cohen, promoted from HEW's ranks, to be as mild in thought as his manner suggests have been rudely surprised. Already the new secretary has proposed (in a speech at Brown University) something which, in American political life, could hardly be more radical: a unified national welfare system of payments to the old, blind, disabled and to dependent children, the size of the cheque to be determined in Washington with little regard for the prevailing local attitudes towards race, laziness, illegitimacy, and other human ills-attitudes which vary picturesquely and arbitrarily from one state to another.

\section{Opinions about Porton}

A NUMBER of eminent people have now publicly expressed their opinions about chemical and biological warfare. Twenty-one fellows of the Royal Society, including eight Nobel laureates, wrote personal letters to the Prime Minister on June 27 asking for all work carried out at the Microbiological Research Establishment at Porton to be published. They are worried about research which leads to the development of offensive weapons. Many scientists apparently believe that this work is indirectly contributing to a stockpiling of offensive biological weapons.

In general, the writers of these letters agree with Mr Tam Dalyell, Labour MP for West Lothian, who considers that the work at MRE should be declassified and the responsibility for research transferred from the Ministry of Defence to a civilian authority. His question to the Prime Minister, asking whether the Government will consider transferring this responsibility to the Ministry of Health, has been postponed for three weeks.

On the same day that the Prime Minister received the letters from the fellows of the Royal Society, eleven members of the Biological Research Advisory Board, which advises MRE on all its activities, wrote to the Times saying that they have full access to all the work at the establishment and are satisfied that it has no military offensive objectives. These eleven scientists, who include Sir Charles Dodds, Sir Ashley Miles and Professor W. J. T. Morgan, are convinced that work is not published only if this involves a risk to national security. They stress that the work carried out at MRE, which as the director has said (Nature, 218,$1114 ; 1968$ ) is concerned with protection against microbiological attack, makes many contributions to medicine, public health and industry. The writers say that statements which contradict this are deplorable and irresponsible.

A similar defence of the Chemical Defence Experimental Establishment at Porton was made by twelve scientists, including Dr J. M. Barnes, Professor R. B. Fisher and Dr D. Tabor, who wrote to the Times on June 26. These scientists said that the establishment and its work, which they know well, is devoted to the protection of Britain from a real threat. They said that no disarmament plan that will work has yet been proposed, and progress is so slow that it may be a very long time before disarmament becomes a reality. Until there is effective disarmament there must be effective protection against chemical attack.

A plea for declassification was made by $\mathrm{Dr} J . H$. Humphrey, who suggested in a letter to the Times on June 29 that a good step towards an attempt to reach an international agreement not to use or manufacture chemical weapons would be for the United Kingdom to show that it does not make or stockpile weapons of this kind. Mr Dalyell has several questions on the House of Commons order paper concerning chemical and biological warfare, and doubtless many more opinions can be expected before there are any signs of official changes.

\section{Change in Medicine}

SHould the medical profession encourage screening as a tool for detecting discase at an early stage ? A World Health Organization publication Principles and Practice of Screening for Disease suggests that screening is not without its snags, and says that the highest rewards will no doubt come from screening of populations in which certain conditions are prevalent and medical care facilities are minimal. Malaria carriers in poorly developed tropical areas are an obvious case. But screening also lends itself to the detection of diseases in developed countries. Anaemia, for one, is particularly suited to screening techniques as are pulmonary tuberculosis, cancer of the cervix and breast and diseases of the eye.

For a disease to be suitable for screening it must be frequent in the population under study, of high morbidity, easily diagnosed by a single sign and there must be a reasonable prospect of cure. Although screening could be carried out by suitably qualified technicians, thereby suving the time of highly trained professional people, in the short term it must add to the doctor's burden as increased detection of disease will lead to greater demand for treatment. Balancing this, however, is the fact that early diagnosis promises better hope of cure and lowers the death rate from malignant disease. In hospitals too, screening of paticnts could lead to a reduction in length of stay, and fewer consultations might be called for. According to the report, the long-term economic aim of screening is to lengthen the productive life of the population, thercby improving the overall economy. But the immediate cost is going to be high and at the moment it looks as though the total cost of screening in a community will be higher than conventional medical care. Nevertheless, the arrival of automation both for carrying out the tests and data processing should lead to a reduction in the cost of sereening.

The report points out that both the medical profession and the public will need to be educated on screening. It suggests that preventive medicine should be taught throughout the medical curriculum and that members of the public should be encouraged to come forward. The report suggests that women should be taught 